\title{
PROGRAM UNGGULAN KAMPUNG IKLIM (PROKLIM) BERBASIS PEMBERDAYAAN MASYARAKAT
}

\author{
Dodi Faedlulloh ${ }^{1}$, Bambang Irawan ${ }^{2}$, Retnayu Prasetyanti ${ }^{3}$ \\ 1,2 Program Studi Administrasi Publik, Universitas 17 Agustus 1945 Jakarta \\ ${ }^{3}$ Sekolah Tinggi Ilmu Administrasi - LAN Jakarta \\ Email: ${ }^{1}$ dodifaedlulloh@gmail.com ; ${ }^{2}$ bambang.irawan@uta45jakarta.ac.id ; \\ ${ }^{3}$ retnayuprasetyanti@yahoo.com
}

\begin{abstract}
This paper is intended to present a comparative analysis of the implementation of a community empowerment based Kampung Climate's Leading Program (ProKlim) in Jati Village, East Jakarta and Kebon Kosong Village, Central Jakarta. The result of this research indicates that both in Kebon Kosong Village and Kelurahan Jati have emphasized aspects of community empowerment in the implementation of ProKlim mainly in climate change adaptation and mitigation activities. Empowerment and participation of communities in Jati Village is considered improperly

Article Histori:

Submited: $10 / 09 / 2018$

Review: 25/09/2018

Editing: 02/04/2019

Publish: 25/04/2019 managed, while in Kebon Kosong Village, the implementation of ProKlim is more coherent and sustainable. However in substance, ProKlim has been well implemented in each locus. Further in practice, ProKlim, with a persistent management, is perceived to be able to manage a microclimate which gives a wider impact on temperature deterioration in the capital city.
\end{abstract}

Keyword: Participation, Climate Change, Kampung Climate's Leading Program, Community Empowerment.

\section{PENDAHULUAN}

Persoalan perubahan iklim sudah menjadi fenomena lingkungan yang nyata dan diakui sebagai salah satu ancaman terbesar bagi kehidupan manusia. Laporan Intergovernmental Panel on Climate Change (IPCC) menyebutkan bahwa kenaikan suhu permukaan bumi (global) berkisar antara $1,35^{\circ} \mathrm{C}$ dan diperkirakan akan terus meningkat antara $1,5-2^{\circ} \mathrm{C}$ pada periode 30 tahun mendatang. Kenaikan suhu bumi meningkatkan ancaman terhadap risiko terjadinya bencana terkait iklim seperti banjir, longsor, kekeringan, gagal panen, kerusakan keragaman hayati, kenaikan muka air laut serta penurunan kualitas kesehatan manusia. Fenomena global warming menjadi pemicu utama reformasi "konstitusi hijau" (green constitution) dalam proses penyelenggaraan pemerintahan.

Green Constitution menjadi dasar penyelenggaraan asas-asas demokrasi lingkungan (ecocracy) yang menjamin prinsip keberlanjutan dalam proses perencanaan pembangunan nasional/lokal. Di sisi lain prinsip-prinsip sustainable 
development yang dilandasi visi perlindungan dan pelestarian fungsi lingkungan hidup telah turut andil sebagai landasan utama tata kelola pemerintahan yang berkelanjutan guna mendukung upaya peningkatan kualitas kesejahteraan masyarakat. Hal ini sesuai dengan amanat konstitusi (Undang-Undang Dasar 1945) pasal $28 \mathrm{H}$ ayat (1) yang menyebutkan bahwa, "Setiap orang lingkungan hidup yang baik dan sehat serta berhak memperoleh pelayanan kesehatan". Undang-undang Nomor 32 Tahun 2009 tentang Perlindungan dan Pengelolaan Lingkungan Hidup juga telah mengatur hak-hak masyarakat terhadap lingkungan hidup ataupun terhadap pengelolaan lingkungan hidup. Pasal 65 mengatur adanya lima hak atas lingkungan hidup, yaitu:

- Setiap orang berhak atas lingkungan hidup yang baik dan sehat sebagai bagian dari hak asasi manusia.

- Setiap orang berhak mendapatkan pendidikan lingkungan hidup, akses informasi, akses partisipasi, dan akses keadilan dalam memenuhi hak atas lingkungan hidup yang baik dan sehat.

- Setiap orang berhak mengajukan usul dan/atau keberatan terhadap rencana usaha dan/atau kegiatan yang diperkirakan dapat menimbulkan dampak terhadap lingkungan hidup.

- Setiap orang berhak untuk berperan dalam perlindungan dan pengelolaan lingkunganhidup sesuai dengan peraturan perundangundangan. 
- Pengendalian kekeringan, banjir, dan longsor;

- Peningkatan ketahanan pangan;

- Pengendalian penyakit terkait iklim;

- Penanganan atau antisipasi kenaikan muka laut, rob, intrusi air laut, abrasi, ablasi atau erosi akibat angin, gelombang tinggi.

- Pengelolaan sampah,limbah padat dan cair;

- Pengolahan dan pemanfaatan air limbah;

- Penggunaan energi baru terbarukan, konservasi dan penghematan energi;

- Budidaya pertanian;

- Peningkatan tutupan vegetasi; dan

- Pencegahan dan penanggulangan kebakaran hutan dan lahan. (Kementrian Lingkungan Hidup dan Kehutanan, 2017a)

Berdasarkan data dari Kementerian Lingkungan Hidup dan Kehutanan, setiap daerah di tingkat dusun/desa atau Kelurahan minimal memiliki satu program unggulan Kampung Iklim. Setidaknya, tercatat sebanyak 180 ProKlim yang tersebar di 69 Kabupaten/Kota pada tahun 2013, pada tahun 2016, jumlah ProKlim nasional di tingkat desa adalah 290 ProKlim, jumlah ini dicanangkan akan meningkat menjadi 2000 ProKlim yang ditargetkan berfungsi secara maksimal pada awal tahun 2019 (Kompas, 2017). Implementasi ProKlim di Provinsi Jakarta tergolong baik, hingga akhir 2016, sebanyak 12 ProKlim telah berfungsi secara aktif di beberapa RW dan Kelurahan.

Program nasional Kampung Iklim dinilai mampu menjadi salah satu solusi pembangunan lokal yang berkelanjutan dengan meningkatkan kesadaran masyarakat terhadap kebersihan lingkungan, kesehatan, pendidikan lingkungan hidup serta tanggung jawab sosial perusahaan dalam pembangunan. Penelitian ini difokuskan pada analisis ProKlim di beberapa Kelurahan di Jakarta, pilot projects ProKlim diantaranya adalah Kelurahan Jati, Rawamangun, Jakarta Timur dan Kelurahan Kebon Kosong, Kemayoran, Jakarta Pusat yang telah mendapatkan apresisasi sebagai pusat studi banding ProKlim di tingkat Provinsi.Kedua Kelurahan tersebut telah berhasil melakukan rekayasa iklim mikro (micro climate) yang berdampak pada penurunan temperatur DKI Jakarta sehingga Jakarta menjadi lebih sejuk dan nyaman.

Analisis penelitian mengenai ProKlim difokuskan pada realisasi prinsip-prinsip sustainable development menggunakan basis pemberdayaan masyarakat. Unsur pemberdayaan diukur dari peran aktif masyarakat dalam ProKlim dapat dikategorikan ke dalam beberapa tingkatan partisipasi, yaitu citizen control, delegate power, partnership, placation, consultation, informing, therapy, manipulation (Arnstein, 1971). Selanjutnya, implementasi prinsipprinsip sustainable development didasarkan pada tiga komponen utama kegiatan ProKlim yaitu kegiatan adaptasi perubahan iklim, kegiatan mitigasi perubahan iklim, dan kelompok masyarakat dan dukungan berkelanjutan. Melalui ProKlim, indikator keberhasilan sustainable development didasarkan pada pendekatan bottom-up berbasis strategi pemberdayaan masyarakat 
yang bertumpu pada empat elemen kunci, yaitu pertumbuhan ekonomi, kesejahteraan sosial, pelestarian lingkungan dan stabilitas politik.

\section{KAJIAN TEORI}

\section{Pembangunan Berkelanjutan}

Pembangunan dapat dikonseptualisasikan sebagai suatu proses perbaikan yang berkesinambungan atas suatu masyarakat atau suatu sistem sosial secara keseluruhan menuju kehidupan yang lebih baik atau lebih manusiawi, dan pembangunan adalah mengadakan atau membuat atau mengatur yang belum ada (Rustiadi, 2009). Wacana lingkungan hidup dan pelestarian alam menjadi bagian penting dari proses pembangunan. Selain itu tumbuhnya kesadaran masyarakat dalam negeri bahwa kelestarian lingkungan sudah merupakan suatu keharusan dan sudah merupakan kebutuhan hidup. Dalam skala negara, implementasi kewajiban dan kesadaran akan kelestarian lingkungan diterjemahkan dalam kebijakan pembangunan yang berkelanjutan. Kebijakan ekonomi hijau dan ekonomi biru adalah salah satu contoh pembangunan yang berlandaskan prinsip sustainability. Pembangunan berkelanjutan berinti pada pencapaian keseimbangan antara pembangunan sector ekonomi, pembangunan sector sosial, dan perlindungan lingkungan.

Pembangunan berkelanjutan diatur secara legal dalam green constitution dan Undang-Undang Nomor 32 Tahun 2009 tentang Perlindungan dan Pengelolaan Lingkungan Hidup. Berdasarkan UndangUndang ini, pembangunan berkelanjutan diartikan sebagai upaya sadar dan terencana yang memadukan aspek lingkungan hidup, sosial, dan ekonomi ke dalam strategi pembangunan untuk menjamin keutuhan lingkungan hidup serta keselamatan, kemampuan, kesejahteraan, dan mutu hidup generasi masa kini dan generasi masa depan. Konsep sustainable development menjadi paradigma baru dalam kajian pembangunan perkotaan yang berorientasi pada prinsip sustainability.

Keberlanjutan lingkungan hidup manusia selain tergantung kepada perlindungan lingkungan alamiah dan upaya pemenuhan akan kebutuhan dasar (hunian, kesehatan, makanan dan pekerjaan), juga meliputi perencanaan lingkungan binaan dengan segala elemen pembentuknya (bangunan, ruang terbuka, norma estetika dan warisan budaya). Di kawasan perkotaan, pembangunan berkelanjutan dalam penataan ruang tidak terbatas pada masalah alokasi/pembagian ruang terbuka (hijau), keseimbangan ekologis, manajemen sumber daya yang tidak tergantikan belaka, namun juga berkaitan erat dengan persoalan sosial dan ekonomi.Hal ini menegaskan bahwa, dalam konteks penataan lingkungan urban terdapat kaitan antara penataan ruang lingkungan perkotaan dengan konsep pembangunan keberlanjutan itu sendiri.

ProKlim merupakan salah satu bentuk pembangunan perkotaan yang berkelanjutan dengan menggunakan pendekatan pemberdayaan masyarakat melalui pengembangan komunitas. Meskipun program ini bersifat nasional dan dapat diimplementasikan di semua wilayah 
baik kota maupun desa, ProKlim di wilayah perkotaan dapat menjadi solusi permasalahan lingkungan hidup seperti polusi, banjir, sampah, lingkungan kumuh, dan penurunan kualitas kesehatan masyarakat. Secara teoritis, kualitas lingkungan kehidupan merupakan salah satu dimensi utama dalam konsep pembangunan berkelanjutan (Hall, 2000). Kini, fokus penelitian keberlanjutan tidak lagi hanya sebatas persoalan lingkungan alami dalam pemahaman ekologi global (kualitas udara, air, keragaman hayati, tanah, mineral dan energi), tapi juga kepada lingkungan binaan manusia, seperti bangunan, infrastruktur, dan ruang terbuka hijau yang menjadi bagian penting dari pembangunan berkelanjutan (Hall \& Richards, 2002).

Tujuan pembangunan berkelanjutan dalam ProKlim terfokus pada integrasi empat aspek utama yaitu keberlanjutan pertumbuhan ekonomi (economic sustainability), keberlanjutan kesejahteraan yang adil dan merata dan menghargai budaya lokal (socio-cultural sustainability), serta keberlanjutan ekologidan ekosistem tata kehidupan yang serasi dan seimbang (ecological sustainability).Selanjutnya aspek tersebut ditambah dengan adanya aspek kelembagaan yang berkelanjutan (institutional sustainability).Secara khusus, indikator pembangunan berkelanjutan dalam ProKlim ditentukan pada tiga komponen dasar ProKlim, yaitu kegiatan adaptasi perubahan iklim, kegiatan mitigasi perubahan iklim, dan kelompok masyarakat dan dukungan berkelanjutan.

\section{Pemberdayaan Masyarakat}

Pemberdayaan secara substansial merupakan proses memutus atau breakdown dari hubungan antara subyek dan obyek. Proses ini mementingkan pengakuan subyek akan kemampuan atau daya yang dimiliki obyek. Secara garis besar, proses ini melihat pentingnya distribusi daya (power) dari subyek ke obyek. Hasil akhir dari proses pemberdayaan adalah beralihnya fungsi individu yang semula menjadi obyek berubah sebagai subyek (yang baru), sehingga realisasi sosial yang ada nantinya hanya akan dicirikan dengan realisasi antara subyek dengan subyek yang lain(Pranarka \& Vidhyandika, 1996).

Upaya pemberdayaan masyarakat harus dilakukan melalui tiga cara (Kartasasmita, 1996). Pertama, menciptakan suasana dan iklim yang memungkinkan potensi masyarakat untuk berkembang.Kondisi ini berdasarkan asumsi bahwa setiap individu dan masyarakat memiliki potensi yang dapat dikembangkan.Hakikat kemandirian dan keberdayaan masyarakat adalah keyakinan bahwa setiap individu memiliki potensi untuk mengorganisasikan dirinya sendiri yang perlu diberdayakan. Proses pemberdayaan masyarakat berakar kuat pada proses kemandirian kemandirian setiap individu yang kemudian meluas ke keluarga, serta kelompok masyarakat baik di tingkat lokal maupun nasional.

Kedua, memperkuat potensi atau daya yang dimiliki oleh masyarakat dengan menerapkan langkah-langkah nyata, menampung berbagai masukan, 
menyediakan prasarana dan sarana, baik fisik maupun sosial yang dapat diakses oleh masyarakat lapisan bawah. Ketiga, memberdayakan masyarakat dalam arti melindungi yang lemah dan membela kepentingan masyarakat. Artinya, proses pemberdayaan masyarakat didasarkan pada implementasi nilai-nilai social equity yang tidak memberikan keberpihakan pada kalangan masyarakat tertentu.

Dalam ProKlim, strategi pemberdayaan masyarakat dilakukan melalui beberapa cara, yaitu, demokratisasi proses pembangunan. Konsep pemberdayaan memberikan peluang sebesar-besarnya kepada lapisan masyarakat paling bawah (RT/RW/Dusun/Desa) untuk terlibat dalam pengalokasian sumber daya pembangunan.

Pembangunan berkelanjutan yang digerakkan oleh masyarakat sekaligus menjadi wahana pembelajaran pencerdasan bagi masyarakat untuk mengenali kebutuhannya sendiri serta melaksanakan dan melestarikan upaya untuk memenuhi kebutuhannya. Selanjutnya, melalui ProKlim, Badan Pengendalian dan Perlindungan Lingkungan Hidup di setiap daerah memberikan ruang partisipasi publik untuk mendukung upaya penguatan peran organisasi kemasyarakatan lokal dalam pembangunan.

Secara keseluruhan, program pemberdayaan masyarakat harus berorientasi pada prinsip capacity building atau penguatan kapasitas birokrasi lokal guna mendorong peran aktif pemerintah lokal sebagai fasilitator serta otoritas yang memiliki fungsi pengawasan dan monitoring. Di sisi lain, komponen kegiatan ProKlim juga mengedepankan upaya social capital building, yaitu penguatan modal sosial melalui pelembagaan nilai-nilai luhur yang bersifat universal, yakni, kejujuran, kebersamaan, dan kepedulian.

Strategi inti yang relevan dengan ProKlim adalah community development atau pengembangan komunitas. Berkembangnya konsep community development yang berbasis partisipasi dan kemandirian (selfreliance) dalam masyarakat tidak terlepas dari kondisi nyata dan kebutuhan masyarakat. Selain itu, pengembangan komunitas merupakan strategi pemberdayaan masyarakat yang memungkinkan semua subyek pembangunan dapat terlibat dalam setiap proses/kegiatan yang mencakup perencanaan, pengawasan dan evaluasi. Tidak dapat dipungkiri bahwa community development merupakan salah satu metode yang tepat untuk menjawab isu-isu dan masalah-masalah sosial di Indonesia. Terlebih lagi kehidupan sebagian besar masyarakat Indonesia yang masih menerapkan sistem komunal merupakan modal penting bagi pelaksanaan community development.

Community development secara luas dipahami sebagai sebuah proses yang diinisiasi oleh usaha masyarakat sendiri yang diintegrasikan dengan otoritas pemerintah guna memperbaiki kondisisosial, ekonomi, lingkungan, dan kultural komunitas, mengintegrasikan komunitas kedalam kehidupan nasional dan mendorong optimalisasi kontribusi 
komunitas (Alfitri, 2011). Terdapat tiga pendekatan untuk perencanaan community development, yaitu; development forcommunity (pencetus pemberdayaan adalah perusahaan berstatus pendonor, sedangkan komunitas adalah sebagai obyek), development with community (pemberdayaandalamhalinidirumuskanber sama-sama oleh perusahaan pendonor danmasyarakat), dan development to fcommunity (pemberdayaan dengan pendekatan ini berorientasi pada pemenuhan kebutuhan komunitas). Masing-masing pendekatan menentukan tipe dan tingkatan partisipasi masyarakat. Penjelasan mengenai peran dan tingkatan partisipasi masing-masing aktor dapat dilihat dari tabel di bawah ini.

\section{Tabel 1. Pendekatan dalam Community Development}

\begin{tabular}{|l|l|l|l|}
\hline & \multicolumn{1}{|c|}{$\begin{array}{c}\text { Development } \\
\text { for community }\end{array}$} & $\begin{array}{c}\text { Development } \\
\text { with community }\end{array}$ & \multicolumn{1}{|c|}{$\begin{array}{c}\text { Development } \\
\text { of commmunity }\end{array}$} \\
\hline Inisiator & Perusahaan & $\begin{array}{l}\text { Perusahaan dan } \\
\text { masyarakat }\end{array}$ & Masyarakat \\
\hline Corporate & Pendonor & Agen pembangunan & Agen pembangunan \\
\hline Community & Obyek & Obyek atau subyek & $\begin{array}{l}\text { Sebagai subyek } \\
\text { pembangunan }\end{array}$ \\
\hline Goals & Berorientasi hasil & $\begin{array}{l}\text { Berorientasi pada } \\
\text { hasil pembangunan } \\
\text { berproses }\end{array}$ & $\begin{array}{l}\text { Pembangunan } \\
\text { berproses }\end{array}$ \\
\hline Time frame & $\begin{array}{l}\text { Jangka pendek } \\
\text { atau tujuan tertentu }\end{array}$ & $\begin{array}{l}\text { Jangka menengah } \\
\text { atau terus-menerus }\end{array}$ & $\begin{array}{l}\text { Jangka menengah dan } \\
\text { panjang/berkelanjutan }\end{array}$ \\
\hline
\end{tabular}

Sumber: Alfitri (2011)

\section{Peneltian Terdahulu}

Dalam setiap penelitian harus menghadirkan kebaruan (novelty). Akan tetapi setiap penelitian tidak bisa berdiri sendiri dan selalu berkaitan dengan penelitian-penelitian sebelumnya.Dalam konteks ini, peneliti melakukan literature review pada penelitian-penelitian terdahulu yang sesuai dengan objek penelitan ini. Penelitian pertama yang dilakukan oleh
Saweda (2011) pada tahun 2011 dengan judul "Penataan Ruang Perkotaan yang Berkelanjutan, Berdaya Saing dan Berotonomi (Suatu Tinjauan Pustaka)". Penelitian ini menjelaskan tentang transformasi pembangunan kota yang lebih humanis dan berkelanjutan dengan tetap memajukan aspek modernitas dalam pembangunan. Selanjutnya dijelaskan mengenai penataan ruang/spasial yang didasarkan pada konsep pembangunan ruang terbuka hijau. Hasil penelitian yang dapat dijadikan acuan adalah konsep pembangunan hijau perkotaan dan didukung oleh Good Local Governance dalam kerangka Good Environmental Governance. Kajian ini dapat menjadi referensi penting untuk program Kampung Iklim.

Penelitian selanjutnya yang peneliti rujuk untuk direview adalah penelitian karya Anandita dkk (2014) yang berjudul Pelaksanaan Pembangunan Sarana Prasarana Lingkungan Sebagai Wujud Program Pemberdayaan Masyarakat di Kelurahan Dinoyo Kota Malang. Referensi yang dapat dikaji dari penelitian ini adalah realisasi konsep pemberdayaan masyarakat perkotaan dalam pembangunan lingkungan. Karakter masyarakat urban, tipologi partisipasi dan strategi pemberdayaan yang digunakan dalam penelitian ini dapat menjadi rujukan untuk mempertajam analisis tentang implementasi pemberdayaan masyarakat dalam kegiatan ProKlim di Jakarta.

Penelitian ketiga yaitu karya Nopyandri (2014) yang berjudul Penerapan Prinsip Good Environmental Governance dalam Rangka Perlindungan Pengelolaan 
Lingkungan Hidup. Penelitian Nopyandri memberikan gambaran mengenai pembangunan berkelanjutan dari perspektif Good Environmental Governance yang mengedepankan peran pemerintah dan implementasi green politics.Penelitian ini menyimpulkan bahwa aspek legal dan institusional menjadi dasar utama untuk mewujudkan sustainable institution yang menjadi dasar penting keberhasilan pembangunan berkelanjutan di wilayah perkotaan.

Pada dasarnya masih banyak penelitian lain yang memiliki nilai relevansi dengan penelitian ini. Karena keterkaitan yang begitu kompleks dalam realitas sosial, misal saat melakukan peneltian tentang pembangunan berkelanjutan tentu akan berhubungan dengan konsep partisipasi, kesadaran, resistensi dan sebagainya. Beberapa penelitian yang telah dijelaskan sebelumnya secara tidak langsung memberikan masukan yang penting bagi peneliti baik dalam hal konsep, metedologi maupun informasi. Dibanding dengan peneltian sebelumnya, tentu peneltian ini memiliki perbedaan dan kebaruan, khususnya pada lokus dan fokus yang diteliti, serta elaborasi yang lebih mendalam tentang pembangunan perkotaan yang partisipatif dan berkelanjutan dalam program Kampung Iklim.

\section{METODE}

Secara sistematis, penelitian ini menggunakan metode kualitatif. Metode kualitatif merupakan prosedur pengumpulan data yang menghasilkan data deskriptif berupa kata-kata tertulis atau lisan dari orang-orang dan perilaku yang diamati (Moleong, 2004). Sedangkan untuk memilih informan peneliti menggunakan purposive sampling.Lokasi penelitian dilakukan di Kelurahan Jati, Rawamangun, Jakarta Timur dan Kelurahan Kebon Kosong, Kemayoran, Jakarta Pusat. Untuk mengukur validitas penelitian, peneliti menggunakan triangulasi sumber dengan membandingkan data hasil pengamatan dan wawancara, keadaan dengan perspektif orang, dan hasil wawancara dengan isi dokumen (Moleong, 2004). Untuk mendukung hasil dari penelitian lapangan, peneliti juga menggunakan pendekatan studi kepustakaan dengan penelitian berbasis data sekunder. Studi kepustakaan merupakan teknik pengumpulan data dengan mengadakan studi penelaahan terhadap buku-buku, literatur-literatur, catatan-catatan, laporanlaporan yang ada kaitannya dengan masalah yang hendak dipecahkan (Nazir, 2009).

\section{HASIL DAN PEMBAHASAN}

\section{Mengurai Adaptasi Perubahan Iklim}

Pemberdayaan secara substansial merupakan proses memutus atau breakdown dari hubungan antara subyek dan obyek. Proses ini mementingkan pengakuan subyek akan kemampuan atau daya yang dimiliki obyek. Secara garis besar, proses ini melihat pentingnya distribusi daya (power) dari subyek ke obyek. Hasil akhir dari proses pemberdayaan adalah beralihnya fungsi individu yang semula menjadi obyek 
berubah sebagai subyek (yang baru), sehingga realisasi sosial yang ada nantinya hanya akan dicirikan dengan realisasi antara subjek dengan subjek yang lain (Pranarka \& Vidhyandika, 1996). Dalam konteks pelaksanaan ProKlim, subjek pelaksanan tiada lain adalah masyarakat (kampung) itu sendiri. Oleh karenanya, pelaksanaan ProKlim tidak bisa dilakukan dengan perspektif top-down.Program tersebut perlu dijangkarkan pada partisipasi publik. Tanpa partisipasi, berbagai langkah yang dilakukan oleh pemerintah akan menjadi sia-sia belaka. Harapan dari dilaksanakanya ProKlim adalah membangun masyarakat yang bertanggungjawab dalam perlindungan dan pengelolaan lingkungan. Namun hal yang perlu menjadi catatan, masyarakat akan menjadi bertanggungjawab bila pemerintah pun memiliki kesadaran dan tanggungjawab yang sama. Karena pada dasarnya problem perubahan iklim adalah masalah global yang juga bersifat struktural. Hal ini tidak bisa dilepaskan dari kehidupan masyarakat internasional. Kerusakan yang terjadi pada lingkungan hidup adalah dampak dari pembangunan global yang tidak berbasis pada keberlanjutan manusia. Laporan dengan judul The Limits to Growth yang ditulis Meadows kepada The Club of Rome (Project on the Predicament of Mankind) menjelaskan tentang berbagai permasalahan yang menimpa banyak negara dan perlu perhatian global, yaitu kemajuan industrialisasi, pertumbuhan penduduk, kekurangan pangan, kerusakan sumber daya alam yang tidak terbarui, dan pencemaran lingkungan (Supriadi, 2010). Namun hadirnya ProKlim adalah upaya yang perlu diapresiasi.Lahirnya kebijakan tersebut berangkat dari kesadaran negara tentang bahaya perubahan iklim.

Kembali pada konteks penelitian, salah satu indikator keberhasilan yang ditetapkan oleh KLHK dalam pelaksanaan ProKlim adalah adanya kegiatan adapatasi perubahan iklim. Kegiatan adaptasi perubahan iklim merupakan langkah yang dilakukan untuk meningkatkan kemampuan dalam menyesuaikan diri terhadap perubahan iklim, termasuk keragaman iklim dan kejadian iklim ekstrim sehingga efek rusak dari perubahan iklim tersebut bisa direduksi, begitupula sebaliknya peluang yang terjadi karena perubahan iklim dapat dimanfaatkan oleh masyarakat, serta konsekueni lainnya yang timbul karna perubahan iklim dapat diatasi. Baik di Kelurahan Kebun Kosong, Jakarta Pusat maupun Kelurahan Jati, Jakarta Timur secara bertahap sudah melaksanakan berbagai upaya dalam kegiatan adapatasi perubahan iklim. ProKlim di Kelurahan Jati tepatnya berlokasi di RW 07, program ini sudah diinsiasi pelaksanaanya pada tahun 2014 silam.Sedangkan lokasi ProKlim di Kelurahan Kebon Kosong adalah di RW 06. Dari hasil penelitian, kedua lokasi ProKlim tersebut dominan melaksanakan kegiatan dalam peningkatan ketahan pangan, seperti 1) upaya perlindungan, pengembangan dan pemanfaatan tanaman lokal untuk peningkatan ketahanan pangan, 2) pertanian organik, dan 3) pemanfaatan 
lahan pekarangan dengan tanaman bermanfaat. Kegiatan tersebut, contohnya di Kelurahan Kebon Kosong dilaksanakan dalam wujud pendirian taman kota. Berbagai tanaman hias berjejer rapi di pagar rumah-rumah warga.Pemandangan di wilayah RW 06 Kelurahan Kebon Kosong ini seperti menjadi oase di tengah gersang dan sempitnya ruang kehidupan di Jakarta Pusat. Taman kota yang didirikan warga ini menjadi penyanggah ekosistem keseimbangan lingkungan sekitar Kelurahan Kebon Kosong. Taman tersebut menjadi sarana dan prasarana pengendalian banjir karena bisa bermanfaat sebagai sumber resapan air di lingkungan sekitar. Taman tersebut dikelola dengan basis partisipasi aktif dari warga yang didukung oleh pembinaan yang baik dari pihak aparat Kelurahan Kebon Kosong. Ada kolaborasi yang baik antara pemerintah lokal dengan warga setempat.

Berbeda dengan Kelurahan Kebon Kosong, ProKlim Kelurahan Jati belum terlaksana secara komprehensif, salah satu alasanya karena belum ada titik pusat yang dijadikan sebagai realisasi ProKlim dalam bentuk ruang khusus. Hal ini terjadi karena problem klasik ibu kota, yaitu tidak adanya lahan kosong yang bisa digunakan sebagai taman kota. Namun kendala tersebut tidak membuat warga berhenti untuk berupaya dalam melaksanakan kegiatan adaptasi terhadap iklim.Daerah RW 07 Kelurahan Jati mengoptimalkan pekarangan warga untuk dijadikan lokasi penanaman berbagai tanaman hias dan juga tanaman lainnya agar lingkungan menjadi lebih hijau dan asri. Selain itu, warga Kelurahan Jati pun mengoptimalkan salah satu lahan menjadi taman hijaun yang diberi nama "Taman Hatinya PKK". Dengan kondisi demikian, ProKlim di Kelurahan Jati walau belum memenuhi aspek sarana dan prasarana dalam pengendalian banjir, namun sudah ada ikhtiar dalam melakukan mitigasi perubahan iklim.

Walaupun dalam skala kecil, ProKlim dinilai mampu menurunkan termperatur kawasan karena pengaruh micro-climate. Selain itu ProKlim bermanfaat dalam menjaga ketersediaan air tanah, ketahanan pangan, keanekaragaman hayati, rekreasi bahkan meningkatkan kekompakan bagi warga. Hal ini yang diakui oleh masyarkat sekitar, baik di Kelurahan Kebon Kosong maupun Kelurahan Jati. Impelementasi ProKlim di tingkat warga secara perlahan mampu meningkatkan kebersaman dan kelembagaan di masyarakat.

Pada dasarnya, aparat pelaksana di kedua tempat telah melakukan sosialisasi program dengan sangat baik, warga diundang oleh pemerintah lokal setempat (kelurahan) untuk memberikan edukasi terkait ProKlim. Dalam perspektif pemberdayaan masyarakat yang bersifat bottom-up, pelaksanaan sosialisasi dan edukasi tidaklah cukup, perlu pendampingan dari pemerintah secara serius, sehingga tujuan dari kemandirian warga bukan dengan cara meninggalkan mereka. Pendampingan pihak Kelurahan Kebon Kosong terhadap warga terkait dengan pelaksanaan ProKlim lebih konsisten dan optimal dibanding Kelurahan Jati. 
Secara regulasi, penataan ProKlim diatur sesuai dengan Perpres No. 61/2011 RAN-GRK dan Perpres 71/2011 tentang tata Cara Inventarisasi Emisi GRK sesuai dengan Peraturan MenLH No. 19 tahun 2012 tentang Program Kampung Iklim. Tentunya kedua kampung iklim yang menjadi lokasi penelitian telah menjadikan regulasi tersebut sebagai acuan dalam menjalankannya.Tapi hasil dari pelaksanan kampung iklim sedikit berbeda.

Kelurahan Kebon Kosong membangun taman kota sebagai bagian dari pengendalian kekeringan dan banjir. Namun karena faktor eksternal lebih besar, seperti minimnya fasilitas penyerap air karena dampak pemngunan infrastruktur di Ibu Kota, setiap ada hujan turun terkadang Kelurahan Kebon Kosong masih terkena dampak banjir. Sedangkan untuk kegiatan pengingkatan ketahanan pangan, Kelurahan Kebon kosong melakukan perlindungan, pengembangan dan pemanfaatan tanaman lokal untuk peningkatan ketahanan pangan. Di salah satu titik Kota Hijau Mandiri RW 06 Kebon Kosong seluas 100 meter persegi berhasil panen sampai 80 kilogram ubi. Sedangkan untuk kegiatan pengendalian penyakit terkait iklim, warga sudah terbiasa melaksanakan perilaku hidup bersih dan sehat (PHBS).Dari pihak aparat kelurahan ataupun penggoragnisiran ibu-ibu PKK seringkali melakukan sosialisasi dan penyuluhan kesehatan tentang perilaku hidup bersih.

a. Sedangkan di Kelurahan Jati belum tersedia sarana dan prasarana pengendalian banjir yang dibangun secara khusus sebagai daya dukung pelaksanaan ProKlim. Berbeda dengan kondisi Kelurahan Kebon Kosong yang masih memiliki lahan rawa yang bisa dioptimalkan, Kelurahan Jati belum memiliki lokasi khusus yang bisa digunakan sebagai taman hijau yang cukup luas. Untuk kegiatan peningkatan ketahan pangan dalam ProKlim, pelaksana ProKlim di Kelurahan Jati fokus pemanfaatan lahan pekarangan dengan tanaman bermanfaat.Mengenai hal ini, pemerintah Kelurahan Jati sebenarnya memiliki catatan yang baik. Kantor Kelurahan Jati pernah mendapatkan penghargaan terkait penghijauan di lingkungan kantor kelurahan pada tahun 2013. Harusnya capaian ini bisa menjadi modal awal untuk penyebarluasan kegiatan mitigasi ke masyakarat yang lebih luas.Untuk konteks kegiatan pengendalian penyakit terkait iklim, warga Kelurahan Jati sudah melaksanakan perilaku hidup bersih dan sehat (PHBS) dengan baik. 


\section{Tabel 2. Komprasi KegiatanAdaptasi Perubahan Iklim di Kelurahan Kebon Kosong dan Kelurahan Jati}

\begin{tabular}{|c|c|c|c|}
\hline \multirow[b]{2}{*}{ Lokasi } & \multicolumn{3}{|c|}{ Kegiatan } \\
\hline & $\begin{array}{l}\text { Pengendalian kekeringan, } \\
\text { banjir dan longsor }\end{array}$ & Peningkatan ketahanan pangan & $\begin{array}{c}\text { Pengendalian } \\
\text { penyakit terkait } \\
\text { iklim }\end{array}$ \\
\hline $\begin{array}{l}\text { Kelurahan } \\
\text { Kebon } \\
\text { Kosong }\end{array}$ & $\begin{array}{l}\text { Tersedia sarana dan prasarana } \\
\text { pengendalian banjir dalam } \\
\text { bentuk taman kota }\end{array}$ & $\begin{array}{l}\text { 1. Ada upaya perlindungan, } \\
\text { pengembangan } \\
\text { pemanfaatan tanaman lokal } \\
\text { untuk peningkatan ketahanan } \\
\text { pangan. } \\
\text { 2. Ada pemanfaatan lahan } \\
\text { pekarangan dengan tanaman } \\
\text { bermanfaat }\end{array}$ & $\begin{array}{l}\text { Melaksanakan } \\
\text { perilaku hidup } \\
\text { bersih dan sehat } \\
\text { (PHBS) }\end{array}$ \\
\hline $\begin{array}{l}\text { Kelurahan } \\
\text { Jati }\end{array}$ & $\begin{array}{l}\text { Belum tersedia sarana dan } \\
\text { prasarana pengendalian banjir }\end{array}$ & $\begin{array}{l}\text { Ada pemanfaatan lahan pekarangan } \\
\text { dengan tanaman bermanfaat }\end{array}$ & $\begin{array}{l}\text { Melaksanakan } \\
\text { perilaku hidup } \\
\text { bersih dan sehat } \\
\text { (PHBS) }\end{array}$ \\
\hline
\end{tabular}

Sumber: Data diolah (2018)

\section{Upaya Mitigasi Perubahan Iklim}

Aspek lain yang penting dalam pelaksanaan ProKlim adalah kegiatan mitigasi perubahan iklim. Mitigasi merupakan serangkaian kegiatan yang dilakukan dalam upaya menurunkan tingkat emisi gas rumah kaca sebagai bentuk upaya penanggulangan dampak perubahan iklim. Kegiatan mitigasi dapat dimulai dari hal-hal sederhana di lingkungan sekitar rumah sampai dengan yang dilaksanakan secara berkelompok dengan melibatkan warga di lokasi kampung iklim. Perilaku hemat energi, transportasi hijau, pengelolaan sampah, penanaman pohon serta pengendalian kebakaran lahan dan hutan yang meliatkan masyarakat adalah contoh kegiatan mitigasi yang perlu terus menerus dikampanyekan kepada seluruh pihak (Kementrian Lingkungan Hidup dan Kehutanan, 2017b).

Di kedua lokasi penelitian, aktivitas mitigasi dilakukan secara sederhana, namun tetap melibatkan peran dan partisipasi masyarakat dalam level yang bervariasi di lokasi kampung iklim. Salah satu hal yang menjadi sorotan utama warga adalah mengenai masalah sampah.Ihwal yang penting dari aktivitas ini dikerjakan secara konsisten dan berkelanjutan. Misalkan, ProKlim di Kebon Kosong yang dirintis sejak tahun 2006 ini diawali oleh inisiasi minoritas kreatif lokal yang berasal dari perangkat desa tingkat RT (RT 14/RW 06). Dilatarbelakangi oleh masalah bau tidak sedap yang timbul karena tumpukan sampah yang justru ironinya bukanlah sampah yang berasal dari warga wilayah Kebon Kosong. Perangkat desa yang menjadi inisiator kreatif tidak segan mendorong masyarakat untuk membersihkan tumpukan sampah tersebut dan meminta bantuan langsung kepada Dinas Kehutanan DKI Jakarta. Pemerintah, melalui Dinas Kehutanan DKI Jakarta memberikan tanaman pelindung seperti pohon tanjung, angsana, bungur, kupu-kupu, yang kemudian oleh warga digunakan sebagai bentuk penghijauan dan memanfaatkan rawa tanah yang belum optimal di Kebon Kosong. Sebagian dari 
warga pun ada yang memiliki inisiatif menanam tanaman obat dan tanaman hias untuk mempercantik kelurahan. Dari hal kecil ini kemudian semakin beresonansi dan berjalan lebih sistematis.

Ketika proses penghijauan sudah baik, kemudian perangkat desa mendorong lebih maju capain kolektif tersebut dengan mengadakan pengelolaan Sampah organik. Secara swadaya, mitigasi yang dilaksanakan di Kebon Kosong meningkat dengan membangun bank sampah pada akhir tahun 2013. Dari hasil keuntungan bank sampah tersebut kemudian dijadikan modalitas bagi masyarakat dalam pemberdayaan dengan membangun empat kebun budi daya (budi daya ikan, kebun buah, kebun tani, dan kebun tanaman hias). Situasi ini terus didorong dengan pembangunan lokasi pengolahan sampah ramah lingkungan di daerah Kebon Kosong (Jalan Dakota) pada tahun 2017. Hal ini sebagai afirmative action yang dilakukukan oleh pemerintah (Suku Dinas Lingkungan Hidup Jakarta Pusat) dalam penanggulangan problem sampah yang sering dihadapi masyarakat. Walaupun pembangunan lokasi tersebut belum 100\%, upaya ini menjadi hal yang perlu diapresiasi.Berarti ada keseriusan pemerintah dalam mengatasi masalah sampah.

Pada dasarnya, perangkat desa telah mendorong warga untuk mampu beradaptasi terhadap perubahan iklim yang mencakup keberadaan air, kesehatan lingkungan, dan ketahan pangan.Namun karena terkendala belum tersedianya teknologi dan dukungan sumber daya lain, ada beberapa rencana seperti pembuatan danau buatan, pengukuran emisi, dan water treatment yang belum bisa dilaksanakan di Kelurahan Kebon Kosong. Secara umum, pengembangan komunitas yang terjadi di Kelurahan Kebon Kosong sudah menuju tahap development of community, yakni agensi pembangunan dominan diinisiasi langsung oleh masyarakat setempat. Dalam beberapa konteks, ada peran pemerintah yang memberikan daya dukung untuk membantu komunitas, namun bantuan tersebut berangkat dari aspirasi langsung masyarakat.

Sedangkan di Kelurahan Jati, tahun 2015 mulai mengaktifkan kembali bank sampah. Bank sampah di Kelurahan Jati sebenarnya sudah sudah ada akan tetapi belum begitu berjalan. Momentum reaktivasi bank sampah ketika hadir program Cost Social Responsibilty (CSR) PT Bintang Toejoeh dengan program Tabib Bejo (Tarik balik Bekas Kemasan PT Bintang Toejoeh). Bentuk pemberdayaan yang terlaksana di Kelurahan Jati merupakan manifestasi development with comunity, yakni ada peran perusahaan yang berpatner dengan masyarakat. Dalam praktiknya, secara gradual masyarakat Kelurahan Jati ikut berpartisipasi dan kembali aktif dalam pengelolaan bank sampah tersebut. Setidaknya terkait dengan problem sampah, Kelurahan Jati telah memiliki alternatif sebagai kegiatan mitigasi.

Kegiatan mitigasi lain seperti pengelohan limbah dan penggunaan energi terbarukan belum terlaksana di Kelurahan Kebon Kosong, sedangkan peningkatan tutupan vegetasi masih terbatas dalam bentuk penanaman tanaman di pekarangan rumah warga karena belum ada lahan khusus yang bisa dijadikan sebagai taman kota seperti di Kelurahan Kebon Kosong. 
Tabel 3. Komparasi Kegiatan Mitigasi Perubahan Iklim di Kelurahan Kebon Kosong dan Kelurahan Jati

Kegiatan

\begin{tabular}{ccccc}
\cline { 2 - 5 } Lokasi & $\begin{array}{c}\text { Pengelolaan } \\
\text { sampah dan } \\
\text { limbah padat }\end{array}$ & $\begin{array}{c}\text { Pengolahan dan } \\
\text { pemanfaatan } \\
\text { limbah cair }\end{array}$ & $\begin{array}{c}\text { Penggunaan energy } \\
\text { baru, terbarukan dan } \\
\text { konservasi energi }\end{array}$ & $\begin{array}{c}\text { Peningkatan } \\
\text { tutupan } \\
\text { vegetasi }\end{array}$ \\
\hline $\begin{array}{c}\text { Kelura } \\
\text { han }\end{array}$ & $\begin{array}{c}\text { Bank sampah } \\
\text { Selaras Mandiri }\end{array}$ & Pupuk Kompos & $\begin{array}{c}\text { Masih dalam bentuk } \\
\text { sosialisasi }\end{array}$ & Penghijauan \\
Kobon & $\begin{array}{c}\text { Pembangunan } \\
\text { lokasi }\end{array}$ & & & \\
pengelolaan & & & \\
& sampah & & & Penghijauan \\
Kelura & Bank sampah & Belum ada & Masih dalam bentuk \\
han & Asri Hijau & & sosialisasi & \\
Jati & & & &
\end{tabular}

Sumber: Data diolah (2018)

Praktik Pemberdayaan

Berkembangnya konsep community development yang berbasis partisipasi dan kemandirian (selfreliance) dalam masyarakat tidak terlepas dari kondisi nyata dan kebutuhan masyarakat. Selain itu, pengembangan komunitas merupakan strategi pemberdayaan masyarakat yang memungkinkan semua subyek pembangunan dapat terlibat dalam setiap proses/kegiatan yang mencakup perencanaan, pengawasan dan evaluasi. Tidak dapat dipungkiri bahwa community development merupakan salah satu metode yang tepat untuk menjawab isu-isu dan masalah-masalah sosial di Indonesia.T erlebih lagi kehidupan sebagian besar masyarakat Indonesia yang masih menerapkan sistem komunal merupakan modal penting bagipelaksanaan community development.
Bila dilihat dari perspektif community development(Isbandi, 2010), dinamika permberdayaan dan partisipasi masyarakat yang terjadi di Kelurahan Kebon Kosong lebih koheren dan ada titik kesinambungan, sedangkan di Kelurahan Jati proses community development berjalan naik-turun. Misalnya dalam tahap engagement, perangkat desa dan masyarakat di Kelurahan Kebon Kosong turut serta dalam menentukan lokasi dan sasaran ProKlim dengan observasi dan pengalaman langsung warga terkait dengan tumpukan sampah yang menjadi masalah sehari-hari mereka. Komunikasi awal yang dilakukan melalui musyawarah yang konsisten untuk melihat ketertarikan masyarakat untuk menjalankan ProKlim ini bersama-sama. Sedangkan Kelurahan Jati, partisipasi warga belum muncul saat pada tahap engagement. Sehingga beberapa kegiatan terkait ProKlim belum berjalan optimal di 
awal-awal proses implementasi. Pada tahun 2015 dukungan dari salah satu perusahaan yang menyelenggarakan CSR di Kelurahan Jati menjadi momentum reaktivasi bank sampah sebagai salah satu aktivitas ProKlim.

Pelaksanaan ProKlim pada dasarnya ditujukan untuk melatih dan merawat proses partisipasi masyarakat dan pelaksanaan pemberdayaan. Baik di Kelurahan Kebon Kosong dan Kelurahan Jati, saat ini sudah terbangun kelompok masyarakat yang menggawangi pelaksanaan ProKlim.Namun dari segi tingkat partisipasi dan dinamika kemasyarakatan, Kelurahan Kebon Kosong lebih tinggi.Dalam banyak aspek, warga telah memiliki peran untuk mengkontrol pelaksanaan (citizen control) ProKlim dibanding Kelurahan Jati.Penulusuran awal, hal ini terjadi karena kesadaran masyarakat di Kelurahan Kebon Kosong sudah tinggi.Hal ini terbukti beberapa kali Kelurahan Kebon Kosong mendapatkan penghargaan terkait dengan lingkungan hidup dan keberhasilan ProKlim (2017).

Untuk pengelolaan ruang publik maka diperlukan kontrol yang disepakati secara konsensus (Faedlulloh, Prasetyanti, \& Indrawati, 2017). Ruang-ruang yang melekat dalam praktik ProKlim ini tak lain adalah bagian besar dari ruang publik. Maka diperlukan kerjasama yang baik antara pihak pemerintah dan juga masyarkat dalam proses pelaksanaan ProKlim. Dalam hal ini, sudah ada kerjasama yang baik antara pemerintah dan masyarakat. Pemerintah lokal, yakni pihak Kelurahan Kebon Kosong membina dengan baik para pelaksana ProKlim. Secara regular, pihak kelurahan selalu melakukan sosialisasi dan komunikasi bersama warga. Unsur perusahaan pun ikut terlibat menjadi stakeholder dari ProKlim di Kelurahan Kebon Kosong, salah satunya PT Unilever dalam bentuk bantuan langsung peralatan kebersihan. Titik tekan keberhasilan sebuah program yang berbasis bottom-up adalah partisipasi, sehingga kegiatan yang telaksana bukan sekadar penggugur kewajiban melainkan dampak refleksi kritis dari masyarkat setempat yang sadar akan pentingnya pengendalian perubahan iklim di tingkat lokal/kampung. Memang, dinamika yang terjadi di Kelurahan Kebon Kosong tidak berjalan begitu saja.Ada inisiator dari segelintir perangkat desa (pemimpin lokal) yang konsisten dan setia melaksanakan tanggung-jawab menjaga lingkungan dan mampu menyebarkan kegiatan adaptasi dan mitigasi ke khalayak yang lebih luas akhirnya kapasitas masyarakat pun tumbuh. Secara aktvitas pun berkembang, yang pertama dari sekadar bersih-bersih sampah, kemudian penghijauan kemudian berkembang mendirikan bank sampah sampai dengan rencana-rencana kegiatan mitigasi lainnya.

Hal yang sedikit berbeda terjadi di Kelurahan Jati, dalam dinamikanya, kegiatan masyarakat terkait ProKlim terjadi pasang surut. Momentum reaktivasi bank sampah justru diinisiasi oleh unsur perusahaan, alih-alih masyarakat. Namun sering berjalan, beberapa warga pun turut serta dalam melaksanakan ProKlim tersebut, termasuk pemanfaatan bank 
sampah.Setidaknya ada kelompok masyarakat yang bertanggungjawab dalam menjalankan ProKlim tersebut sambil mencari ritme kerja dengan menyusun struktur organisasi, kepengurusan, aturanaturan agar bisa berkelanjutan.

\section{KESIMPULAN}

Program Kampung Iklim yang dilaksanakan di Kelurahan Kebon Kosong dan Kelurahan Jati saat ini berjalan dengan baik, namun proses pemberdayaan dan partisipasi masyarakat dalam beberapa hal cukup berbeda satu sama lain. Kegiatan adaptasi perubahan iklim di Kelurahan Kebon Kosong menekankan pada pemanfaatan lahan rawa untuk dijadikan sebagai taman kota. Hal ini berkelindan dalam praktik ruang terbuka hijau di Ibu Kota. ProKlim di Kelurahan Kebon Kosong juga mendukung program zero waste, sampah-sampah di sekitar wilayah Kebon Kosong diolah dan diproduksi menajdi pupuk kompos. Taman yang dibangun sebagai lokasi ProKlim dikelola dengan basis partisipasi aktif dari warga yang didukung oleh pembinaan yang baik dari pihak aparat Kelurahan Kebon Kosong.Ada kolaborasi yang baik antara pemerintah lokal dengan warga setempat.

Sedangkan di Kelurahan Jati, walau ada beberapa kendala pada awal pelaksanaan ProKlim terkait dengan komitmen partisipasi warga, akhirnya tercipta momentum pasca kolaborasi warga dengan unsur perusahaan dalam melanjutkan bank sampah.Secara organik, perlahan warga pun turut serta dalam mengoptimalkan pekarangan untuk dijadikan lokasi penanaman berbagai tanaman hias dan juga tanaman lainnya agar lingkungan menjadi lebih hijau dan asri. Selain itu, warga Kelurahan Jati pun mengoptimalkan salah satu lahan menjadi taman hijau yang diberi nama "Taman Hatinya PKK".

Seperti halnya dalam kegiatan adaptasi perubahan iklim, aktivitas mitigasi yang dilakukan di dua lokasi penelitian menyoroti masasalah utama warga mengenai sampah.Kelurahan Kebon Kosong membangun Bank Sampah Selaras Mandiri, yang mana bank sampah ini menjadi daya dukung warga untuk mengkreasi kebun-kebun budidaya lainnya. Selanjutnya daya dukung dari pemerintah kota dalam pengelohan sampah dibangun lokasi pengelolaan sampah di wilayah Kelurahan Kebon Kosong. Sedangkan di Kelurahan Jati sendiri dibangun bank sampah Asri Hijau sebagai hasil kolaborasi dengan salah satu program CSR perusahaan.

Baik dalam aktivitas adaptasi maupun mitigasi perubahan iklim yang dilaksanakan di Kelurahan Kebong Kosong dan Kelurahan Jati sama-sama menekankan pentingnya proses pemberdayaan dan partisipasi masyarakat. Saat ini masyarakat akhirnya lebih berdaya dalam menghadapi perubahan iklim. Memang pada dasarnya, perubahan iklim adalah masalah global yang tidak bisa diselesaikan dalam skala kampung, namun setidaknya langkah-langkah kecil yang dilakukan warga Kelurahan Kebon Kosong dan Kelurahan Jati ini bila dijalankan secara konsisten dan mampu mempengaruhi lokasi-lokasi lainnya, tidak menutup kemungkinan mampu merekayasa iklim mikro yang berdampak 
pada penuruan temperatur di Ibu Kota secara lebih luas.

\section{DAFTAR PUSTAKA}

Alfitri. (2011). Community Development: Teori dan Aplikasi. Yogyakarta: Pustaka Pelajar.

Anandita, D. (2014). Pelaksanaan Pembangunan Sarana Prasarana Lingkungan Sebagai Wujud Program Pemberdayaan Masyarakat di Kelurahan Dinoyo Kota Malang. Jurnal Administrasi Publik (JAP), 1(5), 853-861.

Arnstein, S. R. (1971). Eight Rungs on the Ladder of Citizen Participation. In Citizen Participation: Affecting Community Change. New York: Praeger Publishers.

Faedlulloh, D., Prasetyanti, R., \& Indrawati. (2017). Menggagas Ruang Publik Berbasis Demokrasi Deliberatif: Studi Dinamika Pengelolaan Ruang Publik Terpadu Ramah Anak (RPTRA) di Jakarta Utara. Spirit Publik, 12(2), 43-60.

Hall, D., \& Richards, G. (2002). Tourism and Sustainable Community Development. London: Routledge.

Isbandi. (2010). Pemberdayaan, Pengembangan Masyarakat, dan Intervensi Komunitas: Pengantar Pada Pemikiran dan Pendekatan Praktisi. Jakarta: Lembaga Penerbit Fakultas Ekonomi Universitas Padjajaran.

Kartasasmita, G. (1996). Pembangunan untuk Rakyat: Memadukan Pertumbuhan dan Pemerataan. Jakarta: PT. Pustaka Cidesindo.

Kementrian Lingkungan Hidup dan Kehutanan. (2017a). Program Kampung Iklim. Retrieved from http:// proklim.menlhk.go.id/

Kementrian Lingkungan Hidup dan Kehutanan. (2017b). Road Map Program Kampung Iklim (Proklim) Gerakan Nasional Pengendalian Perubahan Iklim Berbasis Masyarakat. Jakarta: Direktorat Adaptasi Perubahan Iklim Direktorat Jenderal Pengendalian Perubahan Iklim Kementerian Lingkungan Hidup dan Kehutanan.

Kompas. (2017). Sebanyak 2000 Kampung Iklim
Ditargetkan Berfungsi di 2019. Retrieved from http:/ / nasional.kompas.com

Moleong, L. J. (2004). Metode Penelitian Kualitatif. Bandung: PT. Remaja Rosdakarya.

Nazir, M. (2009). Metode Penelitian. Jakarta: Ghalia Indonesia.

Nopyandri. (2014). Penerapan Prinsip Good Environmental Governance dalam Rangka Perlindungan Pengelolaan Lingkungan Hidup. Jurnal Ilmu Hukum, 80-94.

Pranarka, A. M. ., \& Vidhyandika. (1996). Pemberdayaan: Konsep, Kebijakan dan Implementasi. Jakarta: Center of Strategic and International Studies.

Rustiadi, dkk. (2009). Perencanaan dan Pengembangan Wilayah. Jakarta: Yayasan Obor Indonesia.

Saweda, I. W. (2011). Penataan Ruang Perkotaan yang Berkelanjutan, Berdaya Saing dan Berotonomi (Suatu Tinjauan Pustaka). Jurnal Ilmiah Teknik Sipil, 15(2), 113-122.

Supriadi. (2010). Hukum Lingkungan di Indonesia Sebuah Pengantar. Jakarta: Sinar Grafika. 